\title{
How do information technology and knowledge management affect SMEs' responsiveness to the coronavirus crisis?
}

\section{Naief G. Azyabi}

E-mail: nazyabi@jazanu.edu.sa

Jazan University

Address: Jazan 45142, Saudi Arabia

\begin{abstract}
All organizations have been affected by the coronavirus pandemic in different ways. Small and medium-sized enterprises (SMEs) are more vulnerable to changes due to their limited resources. However, the capabilities of information technologies and processes of knowledge management can assist these enterprises to survive and respond appropriately to changes. Thus, this study aims to assess the extent to which information technology capabilities influence the responsiveness of SMEs to challenges that have emerged during the coronavirus crisis. It also investigates the degree to which knowledge management affects such a relationship in the context of Saudi Arabia. The study includes developing a survey as a data collection method. The responses from 136 SMEs were used to make an analysis and, consequently, draw a conclusion. It has been found that IT capabilities positively influence SMEs' responsiveness to changes brought by coronavirus, through supporting work flexibility and providing a wide range of options in the supply chain, processes, and sales. It further found that knowledge management mediates the relationship between IT capabilities and SMEs' responsiveness.
\end{abstract}

Key words: IT capabilities; small and medium-sized enterprises (SMEs); responsiveness; knowledge management; Saudi Arabia.

Citation: Azyabi N.G. (2021) How do information technology and knowledge management affect SMEs' responsiveness to the coronavirus crisis? Business Informatics, vol. 15, no 2, pp. 75-90.

DOI: 10.17323/2587-814X.2021.2.75.90 


\section{Introduction}

$\mathrm{T}$ There are numerous ways that the coronavirus pandemic (COVID-19) affects the economy, particularly for Small and Medium-Sized Enterprises (SMEs). SMEs experience challenges such as limited resources can hinder the investment in topnotch information technology (IT) systems for efficient operations [1]. In terms of revenue, the abrupt and drastic loss of competition and profits for SMEs severely impacts their operating ability or generates a significant cash deficit. Also, the loss of jobs, concern about contagion, and increased insecurity are causing consumers to lower spending and consumption. This is compounded by the laying-off of employees and businesses unable to pay salaries. More commonly than other companies, SMEs are likely to suffer from social distancing [2].

SMEs contribute significantly to economic progress in any given country, particularly, the developing nations. In Saudi Arabia, the bulk of the companies are SMEs, with added value and employment. However, the prevalence of SMEs is more significant in some regions and sectors that have been impacted. The number of suppliers to SMEs also is lower. Furthermore, the vulnerability of SMEs increases by relying on suppliers from countries and regions with more COVID-19 [3]. Based on a decrease in global demand for their goods and services, businesses, including SMEs, will bear the brunt.

Moreover, it could be more difficult for SMEs to obtain information not only about steps to avoid the spread of the virus but also about potential business strategies to mitigate the shock and policy support initiatives. These are some severe challenges that SMEs are encountering in the midst of the pandemic, as well as in the post-coronavirus period. Since SMEs have different conditions, countries have adopted initiatives to support them. In particular, in this challenging period, several countries are urgently adopting policies to help
SMEs and self-employed workers, with a heavy emphasis on short-term liquidity initiatives.

Research on the responses of SMEs to such a major and comprehensive pandemic remains limited. Thus, the need is still high to understand the behaviour of this type of organization, and how they use IT to survive during this crisis and minimize its effects. This research is considered a contribution on both theoretical and practical sides. In terms of theoretical contribution, it provides a framework that combines the effects of both IT and KM in enhancing SMEs' capabilities and responsiveness. Such a framework will be useful and adaptable in studying or explaining other capabilities of SMEs. The contribution of this research is represented by exploring the ability of SMEs in the Kingdom of Saudi Arabia to adapt and cope with the pressures of the coronavirus pandemic. Furthermore, the contribution is presented through developing and testing a framework that can:

$\downarrow$ provide a better understanding of IT utilization among SMEs;

$\checkmark$ explain the effect of IT and KM processes on SMEs responses to crises.

On the practical side, this framework can guide SMEs to the best way to handle crises through proper utilization of IT and good management of knowledge.

Understanding how IT can be utilized by SMEs to survive and respond to changes could contribute to both SMEs and IT literature. Moreover, Research on SMEs' utilization of IT and knowledge management is limited in the Saudi context. Thus, this research is an attempt to fill such a gap.

This research aims to investigate the relationship between IT capabilities and Saudi SMEs' responsiveness to the coronavirus crisis. It further explores the impacts of knowledge management (KM) processes as a mediating factor of such a relationship. This research is an attempt to answer the following questions: 
To what extent do IT capabilities influence SMEs' responsiveness to the coronavirus crisis?

To what extent do KM processes mediate such influence?

\section{Literature review}

\subsection{IT and responsiveness capabilities in SMEs}

Research has made a significant contribution to understanding the impact of the environment on IT systems [4]. However, there are gaps in the approaches that organizations, specifically SMEs, use to respond to changes in the external environment. The difference consequently raises interest in the need to understand whether IT systems have any role in supporting the SMEs in addressing viable responses in critical moments, such as the presence of a coronavirus pandemic. The relationship between IT capabilities and the level of readiness to respond to various changes in the environment has leaned more on the large enterprises [5]. The understanding of SMEs' response to environmental changes is pertinent for the fact that SMEs are more vulnerable to environmental changes partly due to the limited resources [1]. In order to address such a gap, there is a need to assess how SMEs utilize their IT capabilities to minimize the impacts of environmental changes on them.

According to [6], "dynamic groups of ICT tools, competencies, and expertise, which are exercised through business processes, enable firms to organize activities and leverage ICT assets to achieve the desired results." IT-based capacity is "unique." Companies build capacity to react and organizational characteristics to environmental stimuli.

There are "internally-oriented" (IO) and "externally-oriented" (EO) capabilities [6]. IO technologies are focused on using IT applications for storing information about the internal activities of organizations, such as Enterprise Resource Planning (ERP) solutions. This method can help managers make short-term organizational choices and thereby increase performance and operational control by incorporating data through functions [7]. While technology such as ERP matures, statistics show that practices and IO-based resources among SMEs remain limited.

EO's ability relies on IT to encourage business model creativity, new product development operations, CRM processes, and e-commerce initiatives and to enable businesses to adapt to market changes. The ability to use IT to understand and process external business knowledge is also evident in EO's capacity, which allows companies to reconfigure their products, business models, and supply chain relationships more effectively [6]. More precisely, CRM systems support substantial market intelligence activities. IT supports the new product development, which is critical for customer participation in product innovation, and for supply chain partnership to shorten time-to-market. Because EO resources can also include the opportunity to manage e-commerce programs, the costs of reaching new business segments are controlled. Given the value of IT capabilities, even without the "weaving" of IT, SMEs will achieve strategic agility.

However, the role of these innovations in organizational processes and lowering entry costs in the new market segments can be crucial to their growth by supporting the capacities of the small companies. It can be challenging to implement ERP systems in SMEs, due to their lack of management experience in re-engineering the business process [8], and to their specific characteristics in production management, resulting in profound changes in their organizational routine and modules of standardized ERP software. Given the greater alignment in the concept of IT requirements that they must adopt with partners, IT programs helping EO companies are challenging to implement for SMEs. As such, it requires high levels of social sophistication to apply IT in EO organizational processes. 
Furthermore, travel dependencies are more evident as the use of IT in product creation, and CRM requires a pre-existing build-up of IS supporting internal operations and customer profile and transaction information repositories [6].

\subsection{IT and KM processes in SMES}

Through a reduction in lead times, reduction of overhead cost and product differentiation, KM aims to gain a competitive edge. Firstly, by assessing current circumstances and combining them with previous experience, KM allows companies to reduce their lead times rapidly by recognizing and responding to the evolving marketplace [9]. Secondly, by enhancing commodity quality, which eventually helps consumers, the organization aims to reduce its costs [10]. Third, KM is considered a critical enabler to improve decision making and product changes for organizational advancement [11]. To develop and sustain diverse capabilities, the productivity and effectiveness of information uprooted within an enterprise are essential [12].

KM systems are, therefore, built and implemented to achieve the above three objectives. Sher and Lee [13] have identified three issues in their previous work on KM systems, comprehensive IT design, the degree to which corporate information is built up and preserved, and search for awareness, development and dissemination of IT.

In acquiring and obtaining core expertise, IT is a vital element for organizations, whether adopting personalization or codification KM strategy. KM continues to emphasize both directly and tacitly the incorporation of core business expertise and its importance within the company. In addition to controlling and paying for private information as a central consideration for the KM system, KM takes into account the external aspect [14]. In order to ensure the convergence of the process and information gain, the internal administration role must be combined with external information through the KM system. In a KM report, the following concepts were identified: facilitation of the information, production and information acquisition, marketing knowledge production, marketing knowledge acquisition and alignment with company strategy [15].

The value of managing external knowledge is evident from literature as a specific challenge to achieve the sustainability of competitive advantage more efficiently and effectively than others [16]. It can be argued that the control of external knowledge through IT is indispensable. Furthermore, the management of external knowledge plays a significant role in achieving corporate performance and influencing the company's strategic path. To achieve such a goal, there is a need for an effective compilation of all needed information to design and execute organizational activities in alignment with corporate strategy.

\section{3. $\mathrm{KM}$ and responsiveness capabilities of SMEs}

Roach, Ryman and Makani [17] argue that for most national economies, SMEs and business enterprises are the leading segment drivers. The strategic advantage of capable SMEs is identical, allowing them to create a market niche by changing their product mix to suit the clients' needs [18]. In different parts of the world, SMEs are defined in different ways. Some define them as properties, while others use the criterion of employment, shareholder funds or sales. Some others use the hybrid criterion of a mix of income and jobs. Current literature indicates that SMEs can be distinguished by a variety of essential characteristics from larger firms. This view has now been illustrated by some international business and economic analysis, which proposes that more substantial organizations, for example, from foreign parents, may obtain less knowledge internally than from smaller organizations, because of their ability to produce information on their own [19].

Moreover, the findings discovered in Eastern Europe by Sinani and Meyer's [20] empirical research reveals that relatively smaller organi- 
zations are more knowledgeable than larger entities. Rahayu and Day [21] state that SMEs are more likely than large companies to look for information through experiences with the know-how possessors. Their specific characteristics - management structures, markets, processes, community - are significant features that influence KM activities in SMEs that separate them from large organizations.

Various variables, such as the location of the customer order point, set-up times, manufacturing resources, and system configuration (equipment and workers), affect the responsiveness of a production system. In this regard, three aspects of responsiveness are identified: product, volume and process [22].

\section{Conceptual model and research hypotheses}

This research involves developing a framework that is used to explore how IT capabilities and KM affected SMEs' response to changes caused by the coronavirus pandemic. The hypotheses (Figure 1) indicate that SMEs' responsiveness to change is affected directly by IT (independent variable), and KM is a mediating factor for this effect.

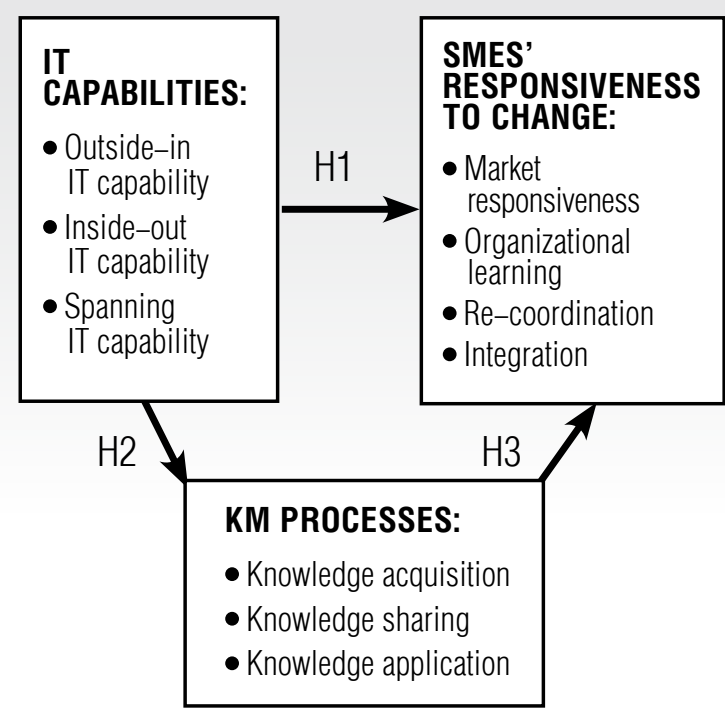

Fig. 1. Research model
The hypotheses of this research are listed below:

\ H1: IT capabilities positively affect SMEs' responsiveness to change;

४ H2: IT capabilities positively affect KM processes;

- H3: KM processes positively affect SMEs' responsiveness to change.

\subsection{IT capabilities}

Zhang and Ziegelmayer [23] assert that every organization that seeks to survive change must be responsive. Flexibility in the IT infrastructure provides the relevant framework to respond to various changes in contemporary society. A firm's responsiveness refers to its ability to react quickly to the possible variations within its environment to try and seize the available opportunities [23]. The effectiveness and efficiency is a reflection of an organization's capacity to sense, internalize and act on stimuli. This is one of the processes that ensure a competitive advantage. The firms with a high level of responsiveness can outperform their competitors by utilizing the available resources to satisfy the needs of customers.

IT capabilities refer to the ability of a firm to install, utilize, integrate and reconfigure the resources from IT systems to enhance the strategies of a business [24]. This kind of approach assists businesses to catalyse their processes and support their strategy. Various approaches can lead organizations to diverse outcomes. Three types of IT capabilities have been identified: outside-in, inside-out and spanning [25]. The three subcomponents (items) can be used to measure IT capabilities. Outside-in capabilities are the external orientation that represents the ability of the firm to develop IT-links with significant business partners. Inside-out IT capabilities refer to the ability of a firm to internally deploy data, networks, as well as relevant infrastructure for its services and applications [26]. Spanning IT capabilities are the ability to integrate both the external and internal IT related factors to gene- 
rate the best performance for a firm [25]. The research adopted a parsimonious yet comprehensive view of the IT capabilities that include: outside-in, inside-out and spanning.

The level of preparing IT personnel for unexpected changes is linked directly to the firm's plans and experience in managing such changes. The competency of such skilled personnel creates a positive impact on the responsiveness of an organization [27].

The present study would consequently seek to bridge the gap by assessing the validity of the statement. This leads to formulating the following hypothesis:

H1: IT capabilities are positively related to SMEs' responsiveness to change.

\subsection{KM processes}

Companies with more significant KM potential are learning to improve their ability to minimize duplication, react rapidly to change, and generate new ideas and creativity [28]. KM processes are measured by three sub-components, which are knowledge acquisition, knowledge sharing and knowledge application.

Knowledge acquisition can be conceptualized as the process involved in gaining knowledge, or only "the method of gaining information" [29]. Information acquired can be implicit, explicit or both. External networks of an organization may be an effective means of acquiring knowledge. Also, formalized and undefined external sources of knowledge provide useful information and promote developments in knowledge [30]. Knowledge sharing is a culture of social interaction involving the exchange of information, experiences and skills between the entire department or organization. The exchange of knowledge involves several collective insights that enable employees to have access to information and to develop and use networks of knowledge inside organizations [31]. Knowledge application is the ability of employees to use the information to develop structures to resolve issues and address problems within an organization and can simply be described as information-application capabilities. Through effective use of information, individuals may make fewer errors or improve their effectiveness and minimize redundancies [12].

IT capabilities enhance the learning process by improving information acquisition, assimilation and implementation by processing contextual intelligence [32]. That is why this skill makes it possible to make the learning cycle in $\mathrm{KM}$ a company as an intellectual resource, which is the foundation for organizational responsiveness. IT ability may strengthen the response, as it encourages the assimilation of information in the process of learning. The IT capabilities of this sort reflect the company's ability to implement cross-functional IT frameworks, such as systems of KM and crosscompany interpreting, to integrate external understanding into internal processes. This skill involves both internally and externally oriented emphasis on promoting the assimilation of information in an organization [33]. In order to test these concepts, the following hypothesis has been framed:

H2: IT capabilities positively affect KM processes.

\subsection{SMEs' responsiveness to change}

SMEs form an integral factor in modern economies. They form a large proportion of all the enterprises present in any given nation. However, they suffer from limitations of resources, which is imperative to respond to the various changes [34]. One of the precarious survival capabilities is responsiveness strategies. In light of the reported research study carried out by Sui and Baum [27] on the failure of more than half of enterprises, it is conceivable that SMEs' ability to adapt to changes is critical for their survival. Firms must always seek to learn from their partners that have more exceptional experiences in terms of responding to crises and mar- 
ket changes [35]. Knowledge plays a crucial role in impacting efforts aimed at supporting an organization to respond to various changes within its environment [36]. KM stems from the effective use of strategies and mechanisms that can ensure the processing of information and data coupled with the utilization of IT and the capacity, in terms of innovation and creativity, from the human beings [37].

Firms usually establish strength to be competitive through finding access to external knowledge. Effective firms' learning processes can support firms' responsiveness. The acquisition of knowledge is likely to enable a firm to respond to prevailing changes, market demands, or changes. A close coordinative relationship with the various partners can also assist an organization to get in-depth, private and rich content that they are likely to use to learn how to respond to the multiple changes in the environment. Integration with other partners can assist an organization in learning collectively on how to handle pertinent changes [38]. Coordinating with different firms can help in creating collective cognitive values. This research investigates the SMEs' responsiveness based on four dimensions: Market Responsiveness, organizational learning, re-coordination and integration. Consequently, the following hypothesis has been articulated:

H3: KM processes positively affect SMEs' responsiveness to change.

\section{Research methodology}

The research adopted a quantitative method of study in which a survey has been used as a data collection instrument. As stated in the introduction section, research questions were formulated to investigate the relationship between IT capabilities, KM processes and Saudi SMEs' responsiveness to the coronavirus crisis. To develop the research framework and instrument, the related literature was reviewed and analysed. Then, the elements for each framework's construct were adopted from previous research. Table 1 shows the main literature from which the survey items were adopted.

\section{Sources of survey's items}

Table 1.

\begin{tabular}{c|c}
\hline Constructs & References \\
\hline $\begin{array}{c}\text { Knowledge } \\
\text { management }\end{array}$ & $\begin{array}{c}\text { Yee-Loong et al., } \\
2014[39]\end{array}$ \\
\hline $\begin{array}{c}\text { Information } \\
\text { technologies } \\
\text { capabilities }\end{array}$ & $\begin{array}{c}\text { Zhang and Ziegelmayer, } \\
2008[23]\end{array}$ \\
\hline SMEs' & Nidumolu and Knots, \\
$1998[40]$ \\
responsiveness & Pavlou and Elsawy, 2006 [41] \\
\hline
\end{tabular}

The questionnaire consists of 30 items distributed on three main constructs as shown in the Table 2.

The research was conducted in the Saudi context, and the parameter which was used in SMEs' definition in this research was the number of employees (organizations with less than 200 employees). Items were translated into clear Arabic to enable targeted participants to comprehend the meaning completely. The targeted participants were asked to show their level of agreement on a five-point Likert scale regarding three main constructs: IT capabilities, SMEs' responsiveness to change and KM processes. The five-point Likert was 1 "strongly disagree," and 5 "strongly agree." SME executives/owners are the main targeted participants. Due to coronavirus lockdown, an online survey method was used to contact the targeted SMEs and collect the required data. All contact details of SMEs were obtained from the Chamber of Commerce without any identifying data. There were 136 SMEs who responded out of 500 targeted SMEs, which counts for $27.2 \%$ as response rate.

The questionnaire elements were tested for their reliability and robustness before the key findings are expanded. Cronbach's Alpha value is calculated to determine the value of the items' 
Table 2.

The survey's items

\begin{tabular}{|c|c|c|}
\hline $\begin{array}{c}\text { Main } \\
\text { construct }\end{array}$ & $\begin{array}{c}\text { Sub- } \\
\text { constructs }\end{array}$ & ltems \\
\hline \multirow{3}{*}{ 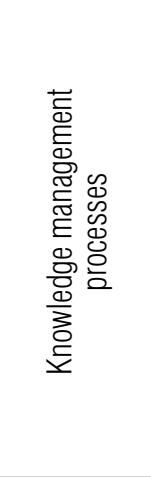 } & $\begin{array}{l}\text { Knowledge } \\
\text { acquisition }\end{array}$ & $\begin{array}{l}\text { KA1: Our organization has processes for generating new knowledge based on existing knowledge. } \\
\text { KA2: Our organization has processes for acquiring customer knowledge. } \\
\text { KA3: Our organization has processes for acquiring knowledge on developing new products/services. }\end{array}$ \\
\hline & $\begin{array}{l}\text { Knowledge } \\
\text { sharing }\end{array}$ & $\begin{array}{l}\text { KS1: Our organization has processes for sharing knowledge throughout the organization. } \\
\text { KS2: Our organization has processes for transferring organizational knowledge to employees. } \\
\text { KS3: Our organization has processes for sharing knowledge among business partners. }\end{array}$ \\
\hline & $\begin{array}{l}\text { Knowledge } \\
\text { application }\end{array}$ & $\begin{array}{l}\text { KAP1: Our organization has processes for integrating different sources and types of knowledge. } \\
\text { KAP2: Our organization has processes for applying experiential knowledge. } \\
\text { KAP3: Our organization has processes for applying knowledge to solve new problems. }\end{array}$ \\
\hline \multirow{3}{*}{ 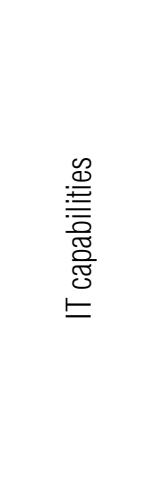 } & $\begin{array}{l}\text { Outside-in IT } \\
\text { capabilities }\end{array}$ & $\begin{array}{l}\text { OIT1: Our organization has technology-based links with customers. } \\
\text { OIT2: Our organization has technology-based links with suppliers. } \\
\text { OIT3: Our organization has IT-based entrepreneurial collaborations with external partners. }\end{array}$ \\
\hline & $\begin{array}{l}\text { Inside-out IT } \\
\text { capabilities }\end{array}$ & $\begin{array}{l}\text { IIT1: Our organization has good appropriateness of the data architectures. } \\
\text { IIT2: Our organization has good appropriateness of network architectures. } \\
\text { IIT3: Our organization has good adequacy of architecture flexibility. }\end{array}$ \\
\hline & $\begin{array}{l}\text { Spanning IT } \\
\text { capabilities }\end{array}$ & $\begin{array}{l}\text { SIT1: Our organization restructure IT work processes to leverage opportunities. } \\
\text { SIT2: Our organization has multidisciplinary teams to blend business and technology expertise. } \\
\text { SIT3: Our organization has a climate that nurtures IT project championship. }\end{array}$ \\
\hline \multirow{4}{*}{ 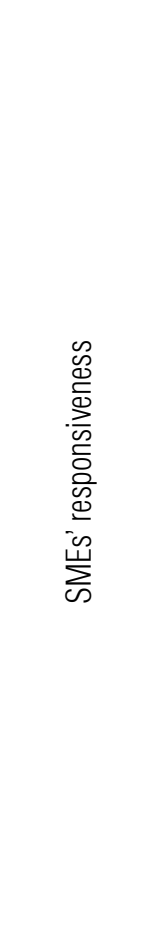 } & $\begin{array}{c}\text { Market } \\
\text { responsiveness }\end{array}$ & $\begin{array}{l}\text { MR1: During the coronavirus crisis, our organization has the agility to respond to environmental } \\
\text { changes. } \\
\text { MR2: During the coronavirus crisis, our organization monitors the environment for the } \\
\text { identification of new business opportunities. } \\
\text { MR3: During the coronavirus crisis, our organization has the agility to develop new products and } \\
\text { services. }\end{array}$ \\
\hline & $\begin{array}{l}\text { Organizational } \\
\text { learning }\end{array}$ & $\begin{array}{l}\text { OL1: Coronavirus crisis increases our organization's desire to improve the ability of employees. } \\
\text { OL2: Coronavirus crisis encourages our organization to have a learning atmosphere. } \\
\text { OL3: Coronavirus crisis encourages our organization to enhance the sharing of ideas. }\end{array}$ \\
\hline & Re-coordination & $\begin{array}{l}\text { RE1: During the coronavirus crisis, our organization has coordination between organizational } \\
\text { processes and employees' abilities. } \\
\text { RE2: During the coronavirus crisis, our organization allocates the assignment of activities to } \\
\text { employees based on their abilities. } \\
\text { RE3: During the coronavirus crisis, our organization engages in effective assignment of resources } \\
\text { to projects and processes. }\end{array}$ \\
\hline & Integration & $\begin{array}{l}\text { INT1: During the coronavirus crisis, our organization engages in defining new activities based on } \\
\text { new situations. } \\
\text { INT2: During the coronavirus crisis, our organization enhances the reintegration of organizational } \\
\text { processes. } \\
\text { INT3: During the coronavirus crisis, there is sufficient cooperation of different departments or sections in } \\
\text { our organization. }\end{array}$ \\
\hline
\end{tabular}


reliability. The factor analysis was carried out to find out the validity of each construct and to report the value of each factor loading. The critical analyses were designed to test the hypotheses and to construct the relationship between variables, mainly via Pearson product-moment correlation and multiple regressions. In the beginning, a general description of the data collected was given and descriptive statistics such as frequency distribution, central pattern and variability measurements were extracted from the use of the SPSS program.

From the data collected, 136 participants responded to the survey. Out of these, the respondents were $36 \%$ Chief Executive officers, $11.8 \%$ directors of accounting and finance, $14.7 \%$ directors of human resources, $17.6 \%$ were directors of IT while others were $19.9 \%$. The data shows that majority of the participants are in managerial positions, which puts them in a better position to answer the research questions.

The demographic analysis (Table 3) shows that there is a wide diversity of participant SMEs in terms of sectors (18.4\% retail firms, $14 \%$ in manufacturing firms, $21.3 \%$ restaurants and food industry, $10.3 \%$ IT services, $14.7 \%$ constructions, and $21.3 \%$ in others sectors). The majority of the firms have been in operation between two to five years, have between 50-249 employees, and with annual revenue of less than 3 million Saudi Arabian Riyals.

\section{Results and analysis}

This research intends to investigate the relationship between IT capabilities and the SMEs' responsiveness during the coronavirus pandemic. The study also aims to investigate whether KM mediates this relationship or not. To achieve these particular investigations, correlation and regression analysis were used. There were 136 SMEs' managers who participated in the survey. The collected data was inserted into SPSS statistics software, and the research hypotheses were examined.
Demographic analysis

\begin{tabular}{|c|c|c|c|}
\hline \multicolumn{2}{|c|}{ SMEs' sector } & \multicolumn{2}{|c|}{ Role of respondents } \\
\hline Sector & $\%$ & Role & $\%$ \\
\hline Retail & $25(18.4 \%)$ & $\begin{array}{c}\text { Chief Executive } \\
\text { Officer }\end{array}$ & $49(36 \%)$ \\
\hline Manufacturing & $19(14 \%)$ & $\begin{array}{l}\text { Director of } \\
\text { Finance }\end{array}$ & $16(11.8 \%)$ \\
\hline $\begin{array}{l}\text { Restaurants and } \\
\text { food industry }\end{array}$ & $29(21.3 \%)$ & Director of HR & $20(14.7 \%)$ \\
\hline IT services & $14(10.3 \%)$ & Director of IT & $24(17.6 \%)$ \\
\hline $\begin{array}{l}\text { Constructions } \\
\text { (real estate, } \\
\text { engineers) }\end{array}$ & $20(14.7 \%)$ & Other & $27(19.9 \%)$ \\
\hline Others & $29(21.3 \%)$ & & \\
\hline
\end{tabular}

\begin{tabular}{|c|c|c|c|c|c|}
\hline \multicolumn{2}{|c|}{$\begin{array}{l}\text { SMEs' } \\
\text { age }\end{array}$} & \multicolumn{2}{|c|}{$\begin{array}{c}\text { Number } \\
\text { of employees }\end{array}$} & \multicolumn{2}{|c|}{$\begin{array}{l}\text { Annual } \\
\text { revenue }\end{array}$} \\
\hline Age & $\%$ & $\begin{array}{c}\text { No of } \\
\text { employees }\end{array}$ & $\%$ & $\begin{array}{l}\text { Rev- } \\
\text { enue }\end{array}$ & $\%$ \\
\hline $\begin{array}{l}<2 \\
\text { years }\end{array}$ & $\begin{array}{c}34 \\
(25 \%)\end{array}$ & $1-5$ & $\begin{array}{c}42 \\
(30.9 \%)\end{array}$ & million & $\begin{array}{c}58 \\
(42.6 \%)\end{array}$ \\
\hline $\begin{array}{c}2-5 \\
\text { years }\end{array}$ & $\begin{array}{c}41 \\
(30.1 \%)\end{array}$ & $6-49$ & $\begin{array}{c}44 \\
(32.4 \%)\end{array}$ & $\begin{array}{l}3-40 \\
\text { million }\end{array}$ & $\begin{array}{c}40 \\
(29.4 \%)\end{array}$ \\
\hline $\begin{array}{l}5-10 \\
\text { years }\end{array}$ & $\begin{array}{c}24 \\
(17.6 \%)\end{array}$ & 50-249 & $\begin{array}{c}50 \\
(36.8 \%)\end{array}$ & $\begin{array}{l}40-200 \\
\text { million }\end{array}$ & $\begin{array}{c}38 \\
(27.9 \%)\end{array}$ \\
\hline $\begin{array}{l}>10 \\
\text { years }\end{array}$ & $\begin{array}{c}37 \\
(27.2 \%)\end{array}$ & & & & \\
\hline
\end{tabular}

\subsection{KMO and Barlett's Test of Sphericity}

KMO's test of sampling adequacy and Barlett's test of sphericity (Table 4) were carried out. KMO's value is 0.955 , with a $p$-value of $0.000(<0.05)$. The Barlett's test of sphericity is also significant $(p=0.000 ;<0.05)$. Principal component analysis can consequently be conducted. The factor loading for the various elements can be as shown in Table 5 . 
Table 4.

KMO's test of sampling adequacy and Barlett's test of sphericity

\begin{tabular}{c|c|c}
\hline \multicolumn{3}{c}{ KMO and Bartlett's test } \\
\hline \multicolumn{2}{c|}{$\begin{array}{c}\text { Kaiser-Meyer-Olkin measure } \\
\text { of sampling adequacy }\end{array}$} & .955 \\
\hline \multirow{3}{*}{$\begin{array}{c}\text { Bartlett's test } \\
\text { of sphericity }\end{array}$} & Approx. Chi-Square & 3583.843 \\
\cline { 2 - 3 } & df & 435 \\
\cline { 2 - 3 } & Sig. & .000 \\
\hline
\end{tabular}

Factor loading for the various items

\begin{tabular}{c|c}
\hline Items & $\begin{array}{c}\text { Factor } \\
\text { Loading }\end{array}$ \\
\hline KA1 & 0.753 \\
\hline KA2 & 0.720 \\
\hline KA3 & 0.785 \\
\hline KS1 & 0.773 \\
\hline KS2 & 0.787 \\
\hline KS3 & 0.784 \\
\hline KAP1 & 0.750 \\
\hline KAP2 & 0.804 \\
\hline KAP3 & 0.810 \\
\hline OIT1 & 0.742 \\
\hline 0IT2 & 0.765 \\
\hline 0IT3 & 0.781 \\
\hline IIT1 & 0.757 \\
\hline IIT2 & 0.775 \\
\hline IIT3 & 0.769 \\
\hline
\end{tabular}

\begin{tabular}{|c|c}
\hline Items & $\begin{array}{c}\text { Factor } \\
\text { Loading }\end{array}$ \\
\hline SIT1 & 0.728 \\
\hline SIT2 & 0.780 \\
\hline SIT3 & 0.772 \\
\hline MR1 & 0.772 \\
\hline MR2 & 0.740 \\
\hline MR3 & 0.779 \\
\hline OL1 & 0.699 \\
\hline OL2 & 0.755 \\
\hline OL3 & 0.748 \\
\hline RE1 & 0.756 \\
\hline RE2 & 0.721 \\
\hline RE3 & 0.737 \\
\hline INT1 & 0.763 \\
\hline INT2 & 0.744 \\
\hline INT3 & 0.714 \\
\hline
\end{tabular}

Rahn [42] states that a factor loading of more than 0.4 is good, and a researcher can carry out further analysis. From the results in Table 5, all items have factor loadings of more than 0.4 and consequently qualify for further analysis.

\section{Cronbach's Alpha} for the variables

\begin{tabular}{c|c|c}
\hline Variable & $\begin{array}{c}\text { Number } \\
\text { of items }\end{array}$ & $\begin{array}{c}\text { Cronbach's } \\
\text { Alpha }\end{array}$ \\
\hline IT capabilities & 9 & 0.937 \\
\hline KM processes & 9 & 0.931 \\
\hline SMEs' responsiveness & 12 & 0.943 \\
\hline
\end{tabular}

\subsection{Cronbach's Alpha}

Cronbach's Alpha was used to measure the level of reliability of the items in the scale for every variable. It measures the level of interrelatedness or the homogeneity of the items [43]. It can be used to assess how a group of given items can measure a construct. The parameter would determine if the individual items would be relied on to measure the intended variables. According to Sharma [44], a reliability coefficient of $\geq 0.7$ is acceptable. Table 6 shows Cronbach's Alpha for the various items and their respective constructs.

The reliability of the various items was calculated using Cronbach's Alpha, as shown in Table 6. The values are higher than 0.7 , which shows higher reliability. The internal consistency of the various research question items when one item is deleted is shown in Table 7. From the results, deleting either of the items would reduce Cronbach's Alpha. Consequently, all items contribute to a higher internal consistency and reliability and can all be used for further analysis.

\subsection{Correlation analysis}

Correlation analysis was carried out to test the identified hypotheses.

H1: IT capabilities positively affect SMEs' responsiveness to change (Table 8 ).

The analysis shows a strong positive correlation between KM processes and SMEs' responsiveness $(r=0.838 ; p<0.05)$. The null hypothesis is, therefore, rejected. 


\section{Cronbach's Alpha if items deleted}

\begin{tabular}{c|c|c|c|c|c}
\multicolumn{2}{c|}{ KM processes } & \multicolumn{2}{c|}{ IT capabilities } & \multicolumn{2}{c}{ SMEs' responsiveness } \\
Items & $\begin{array}{c}\text { Cronbach's Alpha } \\
\text { if item deleted }\end{array}$ & Items & $\begin{array}{c}\text { Cronbach's Alpha } \\
\text { if item deleted }\end{array}$ & Items & $\begin{array}{c}\text { Cronbach's Alpha } \\
\text { if item deleted }\end{array}$ \\
\hline KA1 & .926 & 0IT1 & .930 & MR1 & .939 \\
\hline KA2 & .923 & 0IT2 & .932 & MR2 & .938 \\
\hline KA3 & .923 & 0IT3 & .931 & MR3 & .938 \\
\hline KS1 & .923 & IIT1 & .929 & 0 L 1 & .940 \\
\hline KS2 & .921 & IIT2 & .927 & 0 LL2 & .938 \\
\hline KS3 & .922 & IIT3 & .930 & 0 L3 & .938 \\
\hline KAP1 & .926 & SIT1 & .933 & RE1 & .937 \\
\hline KAP2 & .921 & SIT2 & .931 & RE2 & .938 \\
\hline KAP3 & .923 & SIT3 & .928 & RE3 & .939 \\
\hline & & & & INT1 & .938 \\
\hline & & & & INT2 & .938 \\
\hline
\end{tabular}

Correlation analysis between KM and SMEs' responsiveness

\begin{tabular}{|c|c|c|c|}
\hline & & $\begin{array}{c}\text { Knowledge } \\
\text { manage- } \\
\text { ment }\end{array}$ & $\begin{array}{l}\text { SMEs' } \\
\text { respon- } \\
\text { siveness }\end{array}$ \\
\hline \multirow{3}{*}{$\begin{array}{l}\text { Knowledge } \\
\text { management }\end{array}$} & $\begin{array}{l}\text { Pearson } \\
\text { Correlation }\end{array}$ & 1 & $.838^{\star \star}$ \\
\hline & $\begin{array}{c}\text { Sig. } \\
\text { (2-tailed) }\end{array}$ & & .000 \\
\hline & $\mathrm{N}$ & 136 & 136 \\
\hline \multirow{3}{*}{$\begin{array}{l}\text { SMEs' } \\
\text { respon- } \\
\text { siveness }\end{array}$} & $\begin{array}{l}\text { Pearson } \\
\text { Correlation }\end{array}$ & $.838^{\star \star}$ & 1 \\
\hline & $\begin{array}{c}\text { Sig. } \\
\text { (2-tailed) }\end{array}$ & .000 & \\
\hline & $\mathrm{N}$ & 136 & 136 \\
\hline
\end{tabular}

** Correlation is significant at the 0.01 level (2-tailed)
Table 8. H2: IT capabilities positively affect KM processes ( Table 9).

The analysis shows a strong positive correlation between IT capabilities and KM processes $(r=0.882 ; p<0.05)$.

H3: KM processes positively affect SMEs' responsiveness to change (Table 10).

The results show that there is a strong positive correlation between IT capabilities and SMEs' responsiveness $(r=0.832 ; p<0.05)$.

\subsection{Regression analysis}

A regression analysis was carried out to determine the extent of IT capabilities' influence on SMEs' responsiveness. The results of the analysis are shown in Table 11.

From the analysis shown in the Table 11, IT capabilities are proved to have a strong posi- 
Table 9.

\section{Correlation analysis \\ between IT capabilities and knowledge management}

\begin{tabular}{|c|c|c|c|}
\hline & & $\begin{array}{l}\text { IT capa- } \\
\text { bilities }\end{array}$ & $\begin{array}{c}\text { KM } \\
\text { processes }\end{array}$ \\
\hline \multirow{3}{*}{$\begin{array}{c}\text { IT capa- } \\
\text { bilities }\end{array}$} & $\begin{array}{l}\text { Pearson } \\
\text { Correlation }\end{array}$ & 1 & $.882^{\star \star}$ \\
\hline & Sig. (2-tailed) & & .000 \\
\hline & $\mathrm{N}$ & 136 & 136 \\
\hline \multirow{3}{*}{$\begin{array}{c}\text { KM } \\
\text { processes }\end{array}$} & $\begin{array}{l}\text { Pearson } \\
\text { Correlation }\end{array}$ & $.882^{\star *}$ & 1 \\
\hline & Sig. (2-tailed) & .000 & \\
\hline & $N$ & 136 & 136 \\
\hline
\end{tabular}

${ }^{* *}$ Correlation is significant at the 0.01 level (2-tailed)

tive correlation between IT capabilities and SMEs' responsiveness (R-value 0.832; $\mathrm{P}<0.05$ ); $\mathrm{F}(1,134)=301.158$. The $\beta$-value is $0.832, \mathrm{P}=0.000$, which is as well as a significant value. The R-squared value (0.692) implies that the IT capabilities can account for $69.2 \%$ of the variation in the SMEs' efforts to respond to the impacts instigated by the coronavirus pandemic. The other factors would only account for $31.8 \%$ of the variation. The prediction model for the analysis is the following:

SMEs' responsiveness $=$

$0.772 \cdot$ IT capabilities +0.931 .

\subsection{Mediation test using}

\section{Andrew F. Hayes PROCESS method}

From the results shown in Figure 2 and Tables $12-14$, IT is a significant predictor of knowledge management, $\beta=0.83$; $(p=0.000)$. Multiple regression shows that IT and KM processes are significant predictors of SMEs' responsiveness; $p=0.000$, respectively. IT is a significant predictor of SMEs' responsiveness ( $\beta=0.77 ; p=0.000$ ). The results also prove that the indirect effect of IT capabilities is significantly greater than zero. For instance, in this case, the effect size is 0.38 , with a $95 \%$ confidence interval, which does not
Table 10.

\section{Correlation between IT capabilities and SMEs' responsiveness}

\begin{tabular}{l|c|c|c}
\hline \multicolumn{2}{c|}{} & $\begin{array}{c}\text { IT capa- } \\
\text { bilities }\end{array}$ & $\begin{array}{c}\text { SMEs' } \\
\text { respon- } \\
\text { siveness }\end{array}$ \\
\hline \multirow{3}{*}{$\begin{array}{l}\text { IT } \\
\text { capabilities }\end{array}$} & $\begin{array}{c}\text { Pearson } \\
\text { Correlation }\end{array}$ & 1 & $.832^{\star *}$ \\
\cline { 2 - 4 } & Sig. (2-tailed) & & .000 \\
\cline { 2 - 4 } & $\mathrm{N}$ & 136 & 136 \\
\hline \multirow{3}{*}{$\begin{array}{l}\text { SMEs' } \\
\text { respon- } \\
\text { siveness }\end{array}$} & $\begin{array}{c}\text { Pearson } \\
\text { Correlation }\end{array}$ & $.832^{\star *}$ & 1 \\
\cline { 2 - 4 } & Sig. (2-tailed) & .000 & \\
\cline { 2 - 4 } & $\mathrm{N}$ & 136 & 136 \\
\hline
\end{tabular}

${ }^{* *}$ Correlation is significant at the 0.01 level (2-tailed)

include a zero. The effect is consequently greater than zero at $\alpha=0.05$.

The first step aimed to assess if the predictor variable (IT) significantly predicts the mediator variable (KM processes). In comparison, the second step is examined if both IT and KM processes significantly predict SMEs' responsiveness. The last step is investigated if IT significantly predicts SMEs' responsiveness. The use of both the predictor and the mediator shows a significant decline in $\beta$-value, which proves a partial mediation from the intervening variable. Consequently, it can be argued that KM partially mediates the relationship between IT and the SMEs' responsiveness to the impacts of the coronavirus pandemic.

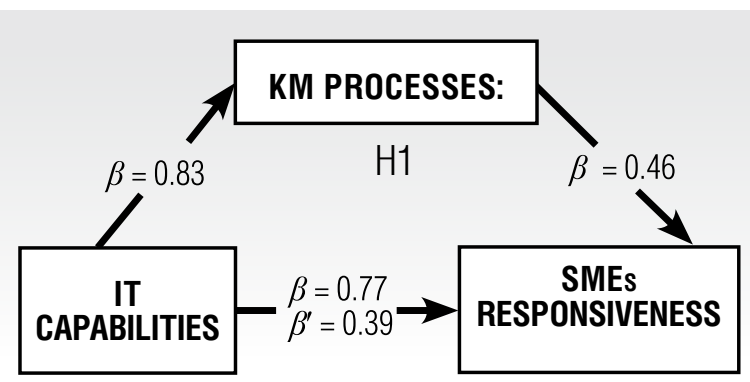

Fig. 2. Path Diagram Model for the relationship among the various variables 
Results of regressing SMEs' responsiveness against IT capabilities

Table 11.

\begin{tabular}{|c|c|c|c|c|c|c|c|c|}
\hline Model & $\mathbf{R}$ & R Square & d.f & $\mathbf{F}$ & & ficients & Beta & Sig. Value \\
\hline 1 & .832 & .692 & $(1,134)$ & 301.158 & Constant $=0.931$ & IT capabilities $=0.772$ & 0.832 & 0.000 \\
\hline
\end{tabular}

Model summary: IT capabilities and knowledge management

\begin{tabular}{l|c|c|c|c|c|c|c}
\hline & R & R-sq. & MSE & $\mathbf{F}$ & $\mathbf{d f 1}$ & $\mathbf{d f 2}$ & $\mathbf{p}$ \\
\hline & .88 & .78 & .09 & 468.26 & 1.00 & 134.00 & .00 \\
\hline & Coeff & $\mathbf{s e}$ & $\mathbf{t}$ & $\mathbf{p}$ & LLCI & ULCI & \\
\hline Constant & .71 & .16 & 4.52 & .00 & .40 & 1.03 & \\
\hline IT_CAP & .83 & .04 & 21.64 & $\mathbf{. 0 0}$ & .75 & .90 & \\
\hline
\end{tabular}

Table 13.

Model summary:

IT capabilities, knowledge management, and SMEs' responsiveness

\begin{tabular}{c|c|c|c|c|c|c|c}
\hline & $\mathbf{R}$ & R-sq. & MSE & $\mathbf{F}$ & $\mathbf{d f 1}$ & $\mathbf{d f 2}$ & $\mathbf{p}$ \\
\hline & .86 & .74 & .10 & 190.05 & 2.00 & 133.00 & .00 \\
\hline Coeff & & $\mathbf{s e}$ & $\mathbf{t}$ & $\mathbf{p}$ & LLCI & ULCI & \\
\hline Constant & .60 & .18 & 3.31 & .00 & .24 & .96 & \\
\hline IT_CAP & .39 & .09 & 4.48 &. $\mathbf{0 0}$ & .22 & .56 & \\
\hline KNWMGT & .46 & .09 & 5.00 & $\mathbf{. 0 0}$ & .28 & .65 & \\
\hline
\end{tabular}

\section{Discussion}

Improved IT around the globe has contributed to tremendous changes in the way SMEs are operating. The presence of a coronavirus pandemic has come with its share of drawbacks with devastating consequences on the limited resources businesses such as SMEs. They need to be flexible in order to escape the challenges imposed by the ever-changing environment. Rigid businesses, in most cases, fail. One of the most significant factors to enhance organizations' flexibility is through adopting the proper IT capabilities. IT capabilities, through supporting efficient management of internal activities, can lead organizations to quick and accurate decisions. Additionally, with the dynamism brought about by the rise of the coronavirus pandemic, IT capabilities can be used to obtain information and knowledge from external sources, which can be an added value to the organization's operations. It further enhances and facilitates communication regardless of geographic restrictions, and to enable work from a distance in some tasks.

Ajayi and Olayungbo [45] affirm that IT plays a vital role in strengthening the competitive advan-

Table 14.

\section{Andrew F. Hayes analysis results Model summary:}

IT capabilities and SMEs' responsiveness

\begin{tabular}{c|c|c|c|c|c|c|c}
\hline & $\mathbf{R}$ & R-sq. & MSE & $\mathbf{F}$ & $\mathbf{d f 1}$ & $\mathbf{d f 2}$ & $\mathbf{p}$ \\
\hline & .83 & .69 & .12 & 301.16 & 1.00 & 134.00 & .00 \\
\hline Coeff & & $\mathbf{s e}$ & $\mathbf{T}$ & $\mathbf{p}$ & LLCI & ULCI & \\
\hline Constant & .93 & .18 & 5.07 & .00 & .57 & 1.29 & \\
\hline IT_CAP & .77 & .04 & 17.35 & $\mathbf{. 0 0}$ & .68 & .86 & \\
\hline
\end{tabular}

The total effect of $X$ on $Y$

\begin{tabular}{c|c|c|c|c|c|c|c}
\hline Effect & se & T & $\mathbf{p}$ & LLCI & ULCI & c_ps & c_cs \\
\hline .77 & .04 & 17.35 & .00 & .68 & .86 & 1.25 & .83 \\
\hline
\end{tabular}

The direct effect of $\mathrm{X}$ on $\mathrm{Y}$

\begin{tabular}{c|c|c|c|c|c|c|c}
\hline Effect & $\mathbf{s e}$ & $\mathbf{t}$ & $\mathbf{p}$ & LLCI & ULCI & C'_ps & $\mathbf{c}$ '_cs \\
\hline .39 & .09 & 4.48 & .00 & .22 & .56 & .63 & .42 \\
\hline
\end{tabular}

Indirect effect(s) of X on Y:

\begin{tabular}{l|c|c|c|c}
\hline & Effect & BootSE & BootLLCI & BootULCI \\
\hline KNWMGT & .38 & .09 & .22 & $\mathbf{. 5 5}$ \\
\hline
\end{tabular}


tage of SMEs, and can be used to access the international markets. Telecommuting, for example, can be used as motivational factors for individuals to work for SMEs. The use of information technology is a motivator for young employees whose firms are unable to pay higher salaries due to the impacts of the coronavirus. Using information technology allows employees to operate from home and works to curb the spread of coronavirus. SMEs can consequently minimize the number of workers in the office to allow the majority to work from home. Enterprises can, therefore, work as they follow directives from the Health authorities.

Knowledge can be acquired from clients or other firms. Sharing of knowledge with both the internal and external agencies can contribute much to supporting the SMEs to make better decisions on their various operations. This practice can be a contributing factor in dealing with the impacts of the COVID-19 pandemic.

The study also reports that KM processes act as an essential mediator between IT capabilities and the SMEs' responsiveness. The mediation is effected by three facets of KM processes that include knowledge acquisition, knowledge sharing and knowledge application. Vaidyanathan and Kidambi [31] argue that organizations need the exchange of information among employees to allow the provision of insights, develop and use networks of knowledge, particularly in SMEs. The flow of information in a firm facilitates both innovations as well as general develop- ment [29]. The use of social media information, for instance, can help firms to know the reactions of the various firms, present, and potential customers and the kind of services and products highly needed by these customers. Innovative approaches always form the archetypal way to ensure that SMEs thrive in a market characterized by unprecedented changes, challenges and opportunities.

\section{Conclusion}

The study proposed a model that linked IT and SMEs' responsiveness, IT and KM, and KM and SMEs' responsiveness to changes brought by the coronavirus pandemic. The study reveals the relationship between IT capabilities and SMEs' responsiveness. A relationship between KM processes and the SMEs' responsiveness in the wake of the coronavirus pandemic has been revealed. IT capabilities were also assessed to relate to knowledge management processes. The Andrew F. Bayes mediation test carried out ascertained that knowledge management partially mediates between IT capabilities and the SMEs' responsiveness. Information technology consequently can be used to support the operations of SMEs during changes brought about by the coronavirus pandemic. Furthermore, knowledge management processes could be used to support this relationship through the flow of pertinent information for developing the business processes.

\section{References}

1. Pathan Z.H., Jianqiu Z., Latif Z., Memon S., Hao D. (2017) Research on ICT patterns and integration in small and medium enterprises: A case study of Pakistan. International Journal of $u$ - and e-Service, Science and Technology, vol. 10, no 2, pp. 53-64. DOI: 10.14257/ijunesst.2017.10.2.06.

2. Bénassy-Quéré A., Marimon R., Pisani-Ferry J., Reichlin L., Schoenmaker D., Weder B. (2020) COVID-19: Europe needs a catastrophe relief plan. Available at: https://voxeu.org/article/covid-19-europe-needscatastrophe-relief-plan (accessed 11 March 2020).

3. Berger Z.D., Evans N.G., Phelan A.L., Silverman R.D. (2020) Covid-19: control measures must be equitable and inclusive. $B M J, 368, \mathrm{~m} 1141$. DOI: $10.1136 / \mathrm{bmj} . \mathrm{m} 1141$.

4. Benešová D., Hušek M. (2019) Factors for efficient use of information and communication technologies influencing sustainable position of service enterprises in Slovakia. Entrepreneurship and Sustainability Issues, vol. 6, no 3, pp. 1082-1094. DOI: 10.9770/jesi.2019.6.3(9).

5. Dalla Pellegrina L., Frazzoni S., Rotondi Z., Vezzulli A. (2017) Does ICT adoption improve access to credit for small enterprises? Small Business Economics, vol. 48, no 3, pp. 657-679. DOI: 10.1007/s11187-016-9794-x. 
6. Neirotti P., Raguseo E., Paolucci E. (2018) How SMEs develop ICT-based capabilities in response to their environment. Journal of Enterprise Information Management, vol. 31, no 1, pp. 10-37.

DOI: 10.1108/JEIM-09-2016-0158.

7. Mithas S., Rust R.T. (2016) How information technology strategy and investments influence firm performance: Conjecture and empirical evidence. MIS Quarterly, vol. 40, no 1, pp. 223-245. DOI: 10.25300/MISQ/2016/40.1.10.

8. Gupta H., Aye K.T., Balakrishnan R., Rajagopal S., Nguwi Y.Y. (2014) Formulating, implementing and evaluating ERP in small and medium scale industries. International Journal of Advances in Computer Science and Technology, vol. 3, no 6, pp. 386-389.

9. Giampaoli D., Ciambotti M., Bontis N. (2017) Knowledge management, problem solving and performance in top Italian firms. Journal of Knowledge Management, vol. 21, no 2, pp. 355-375. DOI: 10.1108/JKM-03-2016-0113.

10. Azyabi N.G. (2017) The role of information technology in enhancing SMEs capabilities through knowledge management. Journal of Organizational Knowledge Management, vol. 10, no 1, pp. 98-109.

11. Darestani H., Ismail W.K.W., Heng L.H. (2016) Investigating a new framework for the impact of knowledge management strategy on organizational performance. Journal of Soft Computing and Decision Support Systems, vol. 3, no 5, pp. 1-23.

12. Blome C., Schoenherr T., Eckstein D. (2014) The impact of knowledge transfer and complexity on supply chain flexibility: A knowledge-based view. International Journal of Production Economics, vol. 147, part B, pp. 307-316. DOI: 10.1016/j.jpe.2013.02.028.

13. Sher P.J., Lee V.C. (2004) Information technology as a facilitator for enhancing dynamic capabilities through knowledge management. Information \& Management, vol. 41, no 8, pp. 933-945. DOI: 10.1016/j.im.2003.06.004.

14. ul Hasan S., Macchi M., Pozzetti A., Carrasco-Gallego R. (2014) Achieving responsiveness in small and medium-sized enterprises through assemble to order strategy. Proceedings of the IFIP International Conference on Advances in Production Management Systems (APMS 2014), Ajaccio, France, 20-24 September 2014, pp. 208-215.

15. Mao H., Liu S., Zhang J., Deng Z. (2016) Information technology resource, knowledge management capability, and competitive advantage: The moderating role of resource commitment. International Journal of Information Management, vol. 36, no 6, part A, pp. 1062-1074. DOI: 10.1016/j.jiinfomgt.2016.07.001.

16. Nupap S., Chakpitak N., Neubert G., Tra-Ngarn Y. (2016) Knowledge management system for Thai small and medium-sized enterprises. International Journal of Innovation and Learning, vol. 19, no 2, pp. 150-168. DOI: 10.1504/IJIL.2016.074467.

17. Roach D.C., Ryman J.A., Makani J. (2016) Effectuation, innovation and performance in SMEs: an empirical study European Journal of Innovation Management, vol. 19, no 2, pp. 214-238. DOI: 10.1108/EJIM-12-2014-0119.

18. Grace P., Kozak R., Nelson H. (2018) Understanding SME success in the value-added forest products sector: Insights from British Columbia. BioProducts Business, vol. 3, no 9, pp. 107-117. DOI: 10.22382/bpb-2018-009.

19. Mohammed A.A., Hafeez-Baig A., Gururajan R. (2019) An exploratory qualitative research to address processes that are utilised for managing knowledge: a case study in a Queensland Regional University. International Journal of Higher Education and Sustainability, vol. 2, no 3, pp. 173-196. DOI: 10.1504/IJHES.2019.101954.

20. Iwasaki I., Tokunaga M. (2016) Technology transfer and spillovers from FDI in transition economies: A metaanalysis. Journal of Comparative Economics, vol. 44, no 4, pp. 1086-1114. DOI: 10.1016/j.jce.2016.10.005.

21. Rahayu R., Day J. (2015) Determinant factors of e-commerce adoption by SMEs in developing country: evidence from Indonesia. Procedia-Social and Behavioral Sciences, vol. 195, pp. 142-150. DOI: 10.1016/j.sbspro.2015.06.423.

22. Belvedere V., Grando A., Papadimitriou T. (2010) The responsiveness of Italian small-to-medium sized plants: Dimensions and determinants. International Journal of Production Research, vol. 48, no 21, pp. 6481-6498. DOI: 10.1080/00207540903234751.

23. Zhang J., Li H., Ziegelmayer J.L. (2008) An empirical study of the relationship between IT infrastructure flexibility and IT responsiveness in SMEs: A resource-based analysis. Proceedings of the Fourteenth Americas Conference on Information Systems, Toronto, ON, Canada, 14-17 August 2008, pp. 1-7.

24. Cai Z., Huang Q., Liu H., Liang L. (2016) The moderating role of information technology capability in the relationship between supply chain collaboration and organizational responsiveness: Evidence from China. International Journal of Operations and Production Management, vol. 36, no 10, pp. 1247-1271. DOI: 10.1108/IJOPM-08-2014-0406.

25. Wade M., Hulland J. (2004) Review: the resource-based view and information systems research: review, extension, and suggestions for future research. MIS Quarterly, vol. 28, no 1, pp. 107-142. DOI: 10.2307/25148626.

26. Bharadwaj A.S., Sambamurthy V., Zmud R.W. (1999) IT capabilities: theoretical perspectives and empirical operationalization. Proceedings of the 20th International Conference on Information Systems (ICIS 99), Charlotte, North Carolina, USA, 13-15 December 1999, pp. 378-385. 
27. Sui S., Baum M. (2014) Internationalization strategy, firm resources and the survival of SMEs in the export market. Journal of International Business Studies, vol. 45, no 7, pp. 821-841. DOI: 10.1057/jibs.2014.11.

28. Akhtar M.W., Imran M. (2015) Knowledge management process, HRM practices and individual performance. Australian Journal of Social Science Research, vol. 2, no 2, pp. 8-15.

29. Åkerman N. (2015) Knowledge-acquisition strategies and the effects on market knowledge - profiling the internationalizing firm. European Management Journal, vol. 33, no 2, pp. 79-88. DOI: 10.1016/j.emj.2014.06.003.

30. Yu X., Yan J., Assimakopoulos D. (2015) Case analysis of imitative innovation in Chinese manufacturing SMEs: Products, features, barriers and competences for transition. International Journal of Information Management, vol. 35, no 4, pp. 520-525. DOI: 10.1016/j.ijinfomgt.2015.03.003.

31. Vaidyanathan S., Kidambi S.S. (2018) An empirical evaluation of adoption and diffusion of new ICTs for knowledge sharing in IT organizations. International Journal of Web Portals, vol. 10, no 1, pp. 1-14. DOI: 10.4018/IJWP.2018010101.

32. Chakravarty A., Grewal R., Sambamurthy V. (2013) Information technology competencies, organizational agility, and firm performance: Enabling and facilitating roles. Information systems research, vol. 24, no 4, pp. 976-997. DOI: 10.1287/isre.2013.0500.

33. Taylor P. (2015) The importance of information and communication technologies (ICTs): An integration of the extant literature on ICT adoption in small and medium enterprises. International Journal of Economics, Commerce and Management, vol. 3, no 5, pp. 274-290.

34. Gancarczyk M., Gancarczyk J. (2018) Proactive international strategies of cluster SMEs. European Management Journal, vol. 36, no 1, pp. 59-70. DOI: 10.1016/j.emj.2017.03.002.

35. de Jesus Pacheco D.A., Carla S., Jung C.F., Ribeiro J.L.D., Navas H.V.G., Cruz-Machado V.A. (2017) Eco-innovation determinants in manufacturing SMEs: Systematic review and research directions. Journal of Cleaner Production, vol. 142, no 4, pp. 2277-2287. DOI: 10.1016/j.jclepro.2016.11.049.

36. Akram M.U., Chauhan C., Ghosh K., Singh A. (2019) Knowledge management, sustainable business performance and empowering leadership: A firm-level approach. International Journal of Knowledge Management, vol. 15, no 2, pp. 20-35. DOI: 10.4018/IJKM.2019040102.

37. Jorna R. (Ed.) (2017) Sustainable innovation: The organisational, human and knowledge dimension. Routledge.

38. Song J., Li F., Wu D.D., Liang L., Dolgui A. (2017) Supply chain coordination through integration of innovation effort and advertising support. Applied Mathematical Modelling, no 49, pp. 108-123. DOI: 10.1016/j.apm.2017.04.041.

39. Yee-Loong Chong A., Ooi K.B., Bao H., Lin B. (2014) Can e-business adoption be influenced by knowledge management? An empirical analysis of Malaysian SMEs. Journal of Knowledge Management, vol. 18, no 1, pp. 121-136. DOI: 10.1108/JKM-08-2013-0323.

40. Nidumolu S.R., Knotts G.W. (1998) The effects of customizability and reusability on perceived process and competitive performance of software firms. MIS Quarterly, vol. 22, no 2, pp. 105-137.

41. Pavlou P.A., El Sawy O.A. (2006) From IT leveraging competence to competitive advantage in turbulent environments: The case of new product development. Information Systems Research, vol. 17, no 3, pp. 198-227. DOI: 10.1287/isre.1060.0094.

42. Rahn R. (2014) A comprehensive critique of the American College Health Association's National College Health Assessment survey instrument (Doctoral dissertation).

43. Henson R.K. (2001) Teacher self-efficacy: Substantive implications and measurement dilemmas. Presented at the Annual Meeting of the Educational Research Exchange, College Station, TX, USA, 26 January 2001, p. 1-43.

44. Sharma B. (2016) A focus on reliability in developmental research through Cronbach's Alpha among medical, dental and paramedical professionals. Asian Pacific Journal of Health Sciences, vol. 3, no 4, pp. 271-278. DOI: 10.21276/apjhs.2016.3.4.43.

45. Ajayi A., Olayungbo D.O. (2014) ICT adoption in small and medium scale enterprises in Nigeria: An assessment. International Journal of Research, vol. 1, no 9, pp. 889-897.

\section{Naief G. Azyabi}

Ph.D.;

Associate Professor, Department of Management Information Systems, College of Business Administration, Jazan University, Jazan 45142, Saudi Arabia;

E-mail: nazyabi@jazanu.edu.sa

ORCID: 0000-0003-0798-8114 